\begin{tabular}{ll}
\hline & $\begin{array}{l}\text { Thabiea : Journal of Natural Science Teaching } \\
\text { Program Studi Tadris Ilmu Pengetahuan Alam } \\
\text { Institut Agama Islam Negeri Kudus } \\
\text { http://journal.stainkudus.ac.id/index.php/Thabiea } \\
p \text {-issn: } 25808474\end{array}$ \\
\hline
\end{tabular}

\title{
Pelatihan Pengembangan Materi Ajar dalam Bentuk Media Power Point pada Materi Struktur Luar Tumbuhan
}

\author{
Muhamad Jalil ${ }^{\mathrm{a}, 1^{*}}$, IAIN Kudus Jl. Ngembalrejo \\ ${ }^{1}$ muhamadjalil@stainkudus.ac.id* \\ *korespondensi penulis
}

\begin{tabular}{l}
\hline Kata Kunci \\
\hline Materi Ajar \\
Media Powerpoint \\
Pelatihan \\
Struktur Luar pada Tumbuhan
\end{tabular}

\begin{abstract}
ABSTRAK
Tantangan abad 21 adalah bagaimana guru sedapat mungkin mengintegrasikan pembelajaran dengan teknologi informasi. Dosen sering kali menemui slide yang disusun oleh mahasiswa saat presentasi belum baik, misal full text dan tidak kontras. Tujuan penelitian ini adalah: menjelaskan bagaimana pelaksanaan, respon, kendala, dan kesulitan saat terjadinya pelatihan pengembangan materi dalam bentuk slide powerpoint pada materi struktur luar tumbuhan. Pendekatan penelitian berbasis pada penelitian kualitatif. Data diperoleh dari angket, wawancara, dan observasi pada mahasiswa PGMI Semester 4 tahun akademik 2017/2018 semester genap. Analisa data menggunakan versi Miles and Haberman. Hasil penelitian menunjukkan bahwa pelaksanaan pelatihan melalui tiga tahapan yaitu pra-pelatihan, pelatihan dan evaluasi. Pelatihan meliputi $10 \mathrm{menu}$ yaitu: pembuatan judul, kompetensi inti, kompetensi dasar, indikator, peta konsep,apersepsi, sub materi struktur luar pada tumbuhan, memasukkan windows media player, latihan soal, dan menyusun sumber belajar. Seluruh peserta pelatihan menyatakan senang terhadap pelatihan pengembangan materi melalui slide presentasi, $75 \%$ menyatakan bermanfaat, dan $87,25 \%$ menyatakan pelatihan Powerpoint merupakan sesuatu hal yang baru. Kesulitan materi yang dihadapi mahasiswa adalah $50 \%$ berupa penyusunan struktur dan konten materi, 25\% berupa pembuatan template Powerpoint, masing-masing $12,5 \%$ kesulitan membuat hyperlink dan memasukkan windows video player. Kendala teknis yang dihadapi secara umum adalah $62,5 \%$ berupa pengaturan waktu, 25\% SDM, dan 12,\% persediaan laptop yang terbatas.
\end{abstract}

\begin{tabular}{ll}
\hline Key Words & ABSTRACT \\
\hline Outside Structure In Plants & The challenge of the 21st century is how teachers as much as possible \\
Powerpoint Media & integrate learning with information technology. Lecturers often find slides \\
Teaching Materials & prepared by students when the presentation is not good, for example: full \\
Training & text and not contrast. The purpose of this study is to explain how the \\
& implementation, response, constraints, and difficulties during the \\
& development of materials in the form of a powerpoint slide on the material \\
& outside the plant structure. The research approach is based on qualitative \\
& research. Data obtained from questionnaires, interviews, and observations \\
& on PGMI students Semester 4 academic year $2017 / 2018$. Data analysis \\
& using Miles and Haberman version. The results showed that the \\
& implementation of the training through three stages of pre-training, \\
& training and evaluation. Training includes 10 menus, namely: making \\
& titles, core competencies, basic competencies, indicators, concept maps, \\
& aperception, sub material outside structure in plants, insert windows media \\
player, practice questions, and compile learning resources. All the trainees & were pleased with the material development training through the \\
presentation slides, $75 \%$ said they were useful, and $87.25 \%$ said \\
Powerpoint training was something new. The material difficulties faced by \\
students are 50\% in the form of structure and content, 25\% are Powerpoint \\
templates, $12.5 \%$ difficulties create hyperlinks and insert windows video \\
player. Technical obstacles faced in general are $62.5 \%$ in the form of time \\
settings, $25 \%$ HR, and $12, \%$ laptop supplies are limited.
\end{tabular}




\section{Pendahuluan}

Materi ajar merupakan bahan yang akan disampaikan oleh peserta didik. Guru yang profesional cirinya adalah menguasai bahan yang akan diajarkan kepada peserta didik. Dengan menguasai materi tentu akan menambah kepercayaan diri guru saat berada di dalam kelas. Berbeda cerita jika guru yang bersangkutan tidak menguasai materi karena minimnya persiapan tentu akan berpengaruh terhadap kualitas pembelajaran di kelas. Karena itu mempersiapkan materi ajar merupakan hal yang paling vital untuk mewujudkan pembelajaran yang berkualitas. Pepatah mengatakan "naik panggung tanpa persiapan, turun panggung tanpa penghormatan". Pepatah sederhana itu menggambarkan betapa pentingnya persiapan sebelum tampil di depan khalayak.

Persiapan materi seringkali diabaikan oleh guru-guru di kelas dengan sejuta alasan. Kesibukan seringkali dijadikan kambing hitam oleh guru untuk tidak menyiapkan materi ajar sebelum performance di depan kelas. Sesibuk apapun harusnya guru komitmen terhadap tugas yang melekat pada seorang diri guru. Dalam undang-undang No 14 Tahun 2005 tentang guru dan dosen, pendidik memiliki kewajiban yaitu menyiapkan perangkat pembelajaran sebelum KBM.

Pengembangan materi ajar dapat berwujud dalam beraneka ragam bentuk seperti: buku teks, diktat, modul, handout, dan Powerpoint. Sementara itu tantangan abad 21 adalah bagaimana guru sedapat mungkin mengintegrasikan pembelajaran dengan information tekcnology and communication (ICT). Oleh karena itu, perlunya calon guru ke depan dibekali dengan skill dalam mengoperasikan berbagai software yang mendukung pembelajaran berbasis ICT. Salah satu program office yang dapat digunakan untuk menciptakan pembelajaran yang lebih menarik dan kontekstual adalah media Powerpoint. Pembelajaran yang menarik dan kontekstual akan lebih mudah dipahami oleh peserta didik sehingga dapat meningkatkan hasil belajar. Hal ini selaras dengan hasil penelitian dari Elpira dan Ghufron (2015) penelitian ini menunjukkan bahwa penggunaan media Powerpoint IPA terbukti berpengaruh terhadap minat dan hasil belajar.

Namun dalam kenyataan dosen sering kali menemui slide yang disusun oleh mahasiswa saat presentasi masih belum menunjukkan ciriciri Media Powerpoint yang baik. Slide yang dibuat hanya sekedar copy paste dari makalah (full text), pemilihan background dengan tulisan terkadang tidak sesuai atau tidak kontras. Terlalu banyak informasi yang ditampilkan dalam satu slide. Menurut Jayanto (2011), media Powerpoint harus mengikuti slogan singkat, padat, dan jelas. Banyak mahasiswa yang mempresentasikan materi ajar atau makalah hanya seperti membaca ulang sebuah slide demi slide. Materi ajar dalam bentuk media Powerpoint harus dibuat sesingkat mungkin, sepadat mungkin, dan sejelas mungkin.

Kondisi ini perlu dicarikan jalan keluar dengan membekali mahasiswa bagaimana menyusun materi ajar dalam bentuk media Powerpoint supaya lebih singkat, padat, dan jelas. Apalagi perkuliahan yang diampu adalah strategi dan perencanaan pembelajaran MI dengan sub tema pengembangan materi ajar pada MI. Materi ini sangat relevan jika dosen dalam menggunakan metode drill Pelatihan pengembangan materi dalam bentuk slide Powerpoint pada materi struktur luar tumbuhan pada kelas IV MI. Tujuan penelitian ini adalah: Menjelaskan bagaimana pelaksanaan pelatihan pengembangan materi dalam bentuk slide powerpoint pada materi struktur luar tumbuhan pada kelas IV MI; Menjelaskan bagaimana respon mahasiswa setelah dilakukan pelatihan pengembangan materi dalam bentuk slide Powerpoint pada materi struktur luar tumbuhan pada kelas IV MI; dan bagaimana kendala dan kesulitan pelaksanaan pelatihan pengembangan materi dalam bentuk slide powerpoint pada materi struktur luar tumbuhan pada kelas IV MI. 


\section{Metode}

Penelitian ini dilaksanakan di kelas PGMI IAIN Kudus. Pendekatan penelitian berbasis pada penelitian kualitatif menjadi pilihan peneliti, karena metode ini digunakan untuk meneliti pada kondisi objek yang alamiah, dimana peneliti adalah sebagai instrumen kunci (Sugiyono, 2010). Jenis kualitatif dalam penelitian ini adalah berbasis deskriptif kualitatif yakni pendekatan dengan memberikan gambaran sementara berdasarkan data awal yang dimiliki untuk menentukan dan mengembangkan langkah-langkah analisa lanjutan sebagai upaya validasi terhadap kebenaran kesimpulan sebagai hasil.

Sumber data menjadi fokus, di mana sumber data terdiri dari mahasiswa PGMI-B; PGMI-C; PGMI D; PGMI-E; PGMI-LKA di IAIN yang berjumlah 166 mahasiswa. Dari semua kelas diberikan pelatihan pengembangan

Kedua, Wawancara atau interview adalah metode pencarian data secara langsung terhadap subjek dan objek penelitian melalui dialog yang dilakukan oleh pewawancara dan terwawancara. Wawancara ini peneliti lakukan pada mahasiswa sebannya 8 mahasiswa. Jumlah delapan mahasiswa diperoleh dari perhitungan menggunakan rumus Tabel Isaac dan Michael berdasarkan tingkat kesalahan 5\%. Sampel dalam penelitian ini adalah $0,05 \times 166=8$ mahasiswa. Wawancara untuk menggali bagaimana kendala pelaksanaan pelatihan pengembangan materi dalam bentuk slide powerpoint pada materi struktur luar tumbuhan KI dan KD kelas IV MI

Ketiga, angket . lembar angket untuk digunakan mengambil data respon mahasiswa setelah dilakukan pelatihan pengembangan materi dalam bentuk slide Powerpoint pada materi struktur luar tumbuhan KI dan KD kelas IV MI. Angket disebarkan kepada 8 mahasiswa.

Untuk kemudian dilakukan uji keabsahan data dengan pola trianggulasi baik teknik maupun sumber. Sehingga pada proses analisis, data yang diperoleh merupakan data yang memiliki tingkat validasi baik. Pada proses materi. Rincian jumlah masing-masing kelas disajikan pada Tabel 1 berikut.

Tabel 1 Jumlah Sumber Data

\begin{tabular}{llll}
\hline No & \multicolumn{1}{c}{ Kelas } & & Jumlah \\
\hline 1 & PGMI-B & 40 & \\
2 & PGMI-C & 37 & \\
3 & PGMI-D & 35 & \\
4 & PGMI-E & 37 & \\
5 & PGMI-LKA & 17 & \\
& TOTAL & 166 & \\
\hline
\end{tabular}

Sementara itu, langkah-langkah pengumpulan data dilakukan dengan tiga cara, yaitu ; pertama, Observasi adalah kegiatan pemusatan perhatian terhadap suatu objek dengan menggunakan seluruh alat indra (Arikunto, 2013). Di mana observasi dilakukan dengan melihat proses pelatihan pengembangan materi dengan menggunakan media Powerpoint.

analisa data, digunakan pola pendekatan analisis versi Miles and Haberman yang berbasis pada tiga tahap operasional, yaitu display data, reduksi data untuk kemudian dilakukan verfikasi data (Milles \& Huberman, 1992).

\section{Hasil dan pembahasan}

\section{Pelaksanaan dan Pelatihan Pengembangan Materi dengan Media Powerpoint}

\section{Tahap Pra-Pelatihan}

a) Sebagai langkah awal kegiatan pelatihan adalah menyusun rancangan kegiatan yang sesuai dengan kebutuhan peningkatan ketrampilan siswa dalam menguasai slide powerpoint

b) Mengumpulkan informasi terkait KI dan KD yang membelajarkan materi struktur luar pada tumbuhan dan analisis terhadap potensi hambatan

c) Menyampaikan kepada koordinator kelas untuk membawa perlengkapan yang digunakan selama proses pelatihan seperti laptop, rol kabel, LCD Projektor, dan lainlain. 
d) Menyiapkan materi mengenai pengembangan desain materi ajar

e) Menyiapkan desain template Powerpoint

f) Menyiapkan kerangka materi untuk yang akan di tuangkan dalam slide Powerpoint dan terdiri dari 10 unsur, yaitu:

a) Judul

Judul merupakan nama yang dipakai untuk buku, bab dalam buku, kepala berita, dan lain-lain; identitas atau cermin dari jiwa seluruh karya tulis, bersipat menjelaskan diri dan yang manarik perhatian dan adakalanya menentukan wilayah atau lokasi. Judul materi pada slide Powerpoint biasanya terdiri dari judul materi, penulis, mata pelajaran, kelas, dan semester.

\section{b) Kompetensi Inti}

Kompetensi Inti adalah tingkat kemampuan untuk mencapai Standar Kompetensi Lulusan yang harus dimiliki oleh peserta didik pada setiap tingkat kelas atau program (Harahap, 2015). Kompetensi Inti merupakan terjemahan atau operasionalisasi SKL dalam bentuk kualitas. Kompetensi inti bukan untuk diajarkan, melainkan untuk dibentuk melalui pembelajaran mata pelajaran yang relevan. Setiap mata pelajaran harus tunduk pada kompetensi inti yang telah dirumuskan. Dengan kata lain, semua mata pelajaran yang diajarkan dan dipelajari pada kelas tersebut harus berkontribusi terhadap pembentukan kompetensi inti. Ibaratnya, kompetensi inti merupakan pengikat kompetensi-kompetensi yang harus dihasilkan dengan mempelajari setiap mata pelajaran.

Di sini kompetensi inti berperan sebagai integrator horizontal antarmatapelajaran. Dengan pengertian ini, kompetensi inti adalah bebas dari mata pelajaran karena tidak mewakili mata pelajaran tertentu. Kompetensi inti merupakan kebutuhan kompetensi peserta didik, sedangkan mata pelajaran adalah pasokan kompetensi dasar yang akan diserap peserta didik melalui proses pembelajaran yang tepat. Kompetensi Inti terdiri atas: (a) Kompetensi Inti sikap spiritual; (b) Kompetensi Inti sikap sosial; (c) Kompetensi Inti pengetahuan; dan (d) Kompetensi Inti keterampilan.

\section{c) Kompetensi Dasar}

Kompetensi Dasar pada Kurikulum 2013 Sekolah Menengah Pertama/Madrasah Tsanawiyah berisikan kemampuan dan muatan pembelajaran untuk mata pelajaran pada Sekolah Menengah Pertama/Madrasah Tsanawiyah yang mengacu pada Kompetensi Inti.

\section{d) Indikator}

Indikator pencapaian kompetensi adalah: (a) perilaku yang dapat diukur dan/atau diobservasi untuk kompetensi dasar (KD) pada kompetensi inti (KI)-3 dan KI-4; dan (b) perilaku yang dapat diobservasi untuk disimpulkan sebagai pemenuhan KD pada KI-1 dan KI-2, yang kedua-duanya menjadi acuan penilaian mata pelajaran.

\section{e) Peta Konsep}

Strategi peta konsep merupakan salah satu bagian dari strategi organisasi. Strategi organisasi bertujuan untuk membantu meningkatkan pemahaman terutama dilakukan dengan menggunakan pengorganisasian bahanbahan baru (Eryanti, 2015). Teori yang digunakan sebagai dasar untuk menjawab permasalahan diatas bertolak dari konsep belajar bermakna David Ausubel. Ausubel mengemukakan bahwa faktor yang paling penting yang mempengaruhi belajar ialah apa yang telah diketahui oleh peserta didik. Menurut Trianto, dengan demikian agar terjadi belajar bermakna, konsep baru atau informasi baru harus dikaitkan dengan konsep-konsep yang sudah ada dalam struktur kognitif siswa.

Maka pembelajaran dengan membimbing siswa terampil membuat peta konsep diharapkan dapat meningkatkan hasil pemahaman suatu konsep dengan baik, karena siswa aktif dalam kegiatan belajar mengajar dan guru berperan sebagai fasilitator. Selain itu dalam jejaring dan pemetaan (mapping), peserta didik mengidentifikasi gagasan utama dan kemudian membuat diagram yang menghubungkan semuanya seperti yang dikemukakan Robinson dan Skinner yang dikutip oleh Slavin.

\section{f) Apersepsi}


Apersepsi merupakan stimulus yang diberikan guru kepada siswa pada awal pembelajaran. Kegiatan ini biasanya dipakai untuk merangsang siswa agar tertarik atau minat terhadap sebuah pembelajaran. Kreativitas guru dalam memberikan apersepsi sebagai langkah awal dalam mewujudkan keberhasilan sebuah pembelajaran. Apersepsi dapat diwujudkan dalam bentuk pertanyaan, menampilkan video, dan menunjukkan gambar pada siswa. Tentunya yang ditampilkan di awal pembelajaran hendaknya berkaitan erat dengan proses pembelajaran.

\section{g) Sub Materi}

Sub materi ini adalah bagian yang harus dikembangkan lebih jauh oleh calon guru. Berkaitan dengan materi, maka seorang calon guru terlebih dahulu wajib menganalisis kata kerja operasional yang dibebankan kepada materi. Beban itu bisa dilihat pada kompetensi dasar. Pengetahuan menurut revisi Bloom dibagi menjadi enam tingkatan, yakini: menghafal, memahami, menerapkan, menganalisis, mengevaluasi, dan mencipta. Dari enam tingkatan pengetahuan kompetensi pengetahuan setiap yang dibebankan pada setiap sub materi berbeda. Jika pengetahuan yang hendak dicapai adalah pemahaman maka sedapat mungkin materi yang dituangkan dalam slide presentasi memuat konten-konten yang mampu memahamkan peserta didik.

\section{h) Video}

Video disini adalah satu media pembelajaran yang sangat berguna untuk memvisualisasikan yang abstrak. Tampilan yang dihasilkan video sangat dinamis dan sangat menarik dan interaktif (Syahrowardi \& Permana, 2016).

\section{i) Latihan soal}

Pelatihan soal rencanya mahasiswa akan diajarkan tentang menyusun soal secara online di situs kahoot.com. Situs ini merupakan menyediakan game-game yang disesuaikan dengan kurikulum baik mata pelajaran matematika, sains, ELA dan sejarah. hampir setiap minggu situs ini menambahkan kuis baru (Kahoot, 2018).

\section{j) Sumber Belajar}

Segala sesuatu yang dapat menghasilkan Pesan sebagai bahan/obyek kajian dalam pembelajaran. Pada bagian ini nanti mahasiswa diminta untuk menyiapkan referensi buku IPA dari buku SD/MI Kelas IV atau dapat diperoleh dari situs internet yang relevan.

\section{Tahap Pelatihan}

a) Melakukan kegiatan pelatihan untuk peserta didik

Kegiatan pelatihan dilakukan saat jam perkuliahan dengan durasi waktu $2 \times 50$ menit. Pelatihan dimulai dengan menjelaskan tentang teori bahan ajar kurang lebih 10 menit. Selanjutnya memaparkan struktur atau sistematika materi ajar.

b) Melakukan kegiatan presentasi karya

Kegiatan kegiatan presentasi karya dilakukan saat Tes Akhir Semester (TAS). Masing-masing kelompok mendemonstrasikan hasil karya masing-masing diberi waktu kurang lebih 10 menit. Karya yang sudah dibuat kemudian diupload ke youtube. Hasil yang diunggah di internet harapannya dapat diakses oleh siapa saja dimana dan kapan saja. Sebagaiman amanah pendekatan saintifik juga menyarankan agar peserta didik mampu membentuk jejaring (networking) di tengah gejolak abad informasi. Berikut gambar hasil presentasi karya mahasiswa PGMI semester 4 tahun akademik 2017/2018 semester genap diperlihat pada Gambar 1 berikut.

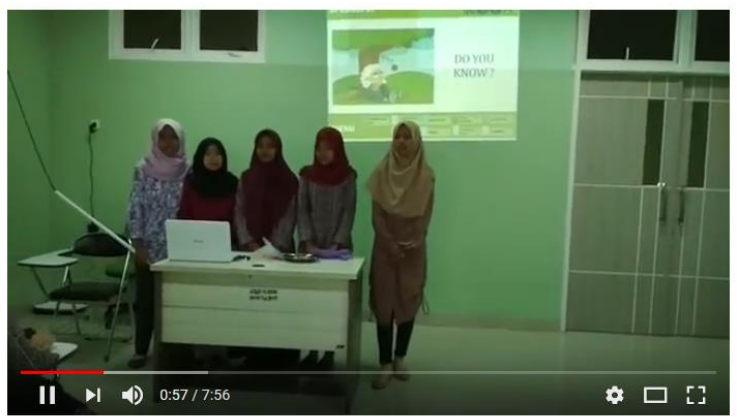

PRESENTASI RPP IPA SD/MI KELAS 4 KEL. 3 PGMI-E/4 IAIN KUDUS 2018)

Gambar 1 Presentasi Karya Mahasiswa yang di Upload di Youtube

Tahap Evaluasi 
Pada tahap evaluasi, peneliti merasa perlu memperbaiki kekurangan-kekurangan yang telah dialami selama pelatihan pengembangan materi di Kelas PGMI-B. Kelemahankelemahan menjadi catatan dan koreksi bersama antara dosen dengan mahasiswa. Hal yang menjadi kendala selama pelatihan tahap pertama merupakan persiapan materi oleh mahasiswa tidak dilakukan sebelumnya. Kondisi ini jelas menghambat mahasiswa dalam mengembangkan struktur dan konten pengembangan materi media Powerpoint. Konten-konten itu memuat KI, KD, indikator, video, dan sub materi. Selain itu perlunya dosen menyusun modul pelatihan agar mahasiswa lebih mudah memahami arahan dan instruksi dari dosen selama proses latihan.

\section{Respon Mahasiswa terkait Pelatihan Pengembangan Materi}

Respon mahasiswa diperoleh dari membagikan angket pertanyaan sebanyak tiga (3) aitem melalui WhatsApp (WA). Dari hasil jawaban mahasiswa kemudian dijadikan acuan untuk melakukan proses interpretasi data dengan pendekatan deskriptif persentase. Pertanyaan pertama berkaitan tentang perasaan mahasiwa setelah diberikan pelatihan pengembangan materi. Dari angket yang disebarkan seluruh mahasiswa menyatakan senang terhadap pelatihan pengembangan materi melalui slide materi. Rasa senang saat mengikuti proses pembelajaran disini menjadi modal berharga bagi mahasiswa untuk mengikuti jalannya proses pembelajaran.

Pembelajaran menyenangkan salah satu amanah yang dituangkan dalam prinsip pembelajaran Kurikulum 2013. Menurut UU No 103 Tahun 2014 bahwa prinsip kegiatan pembelajaran perlu menggunakan prinsip suasana belajar menyenangkan dan menantang . Hasil angket mahasiswa dapat dilihat pada Gambar 2 berikut.

\section{Respon Mahasiswa}

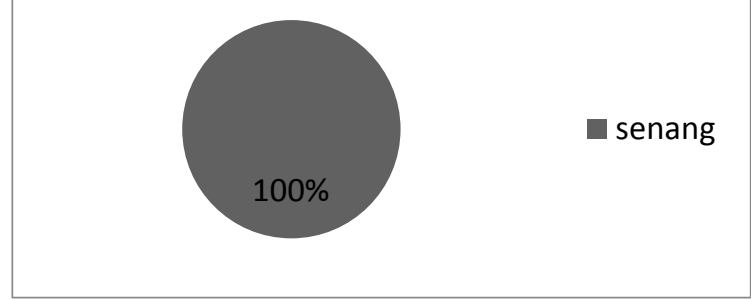

Gambar 2 Respon Senang Terhadap Pelatihan Pengembangan Materi

Selain itu, $75 \%$ mahasiswa juga menyatakan bahwa pelatihan untuk menunjang profesionalisme guru. Media pembelajaran menggunakan program aplikasi MS Powerpoint berupa presentasi yang menarik sebagai untuk membantu guru menyampaikan informasi (Priatmoko, Prasetya, \& Hartati, 2011).Pada materi yang abstrak atau membutuhkan suatu visualisasi tiga dimensi yang penting untuk membantu pemahaman siswa, diberi animasi visualisasi tiga dimensi untuk memahaminya. Hasil angket mahasiswa dapat dilihat pada Gambar 3 berikut.

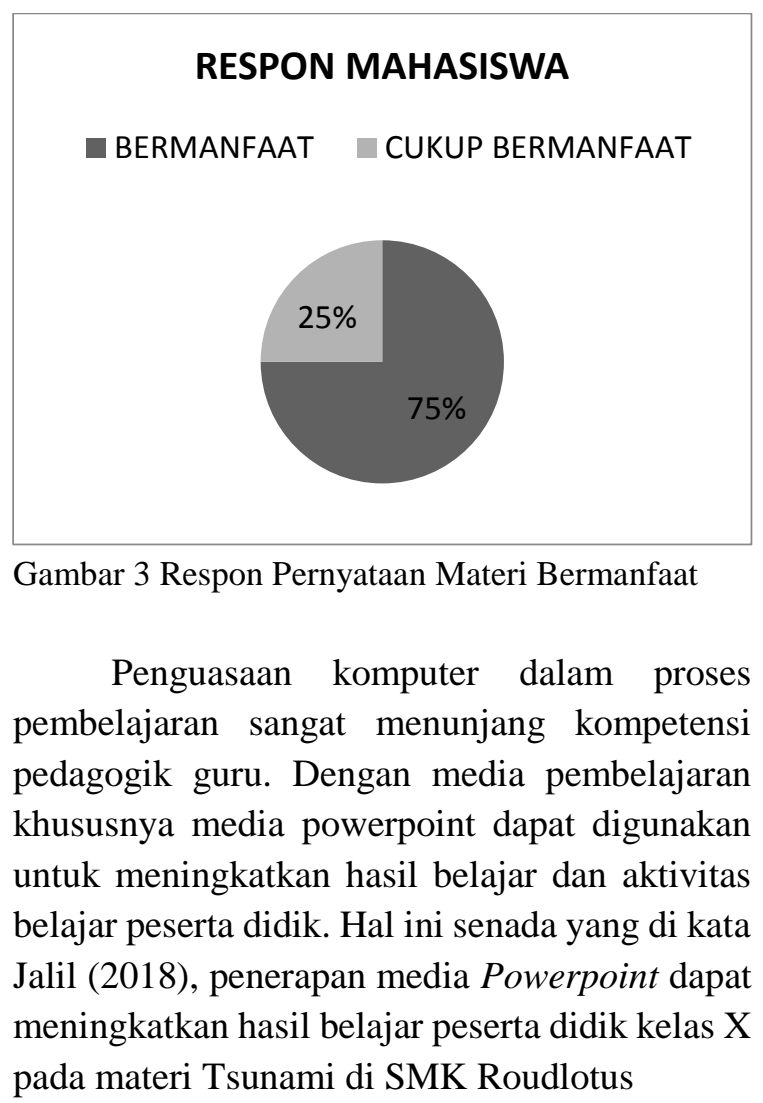


Saidiyyah, yaitu pada dari 48,53 meningkat menjadi 77,81. Selain bermanfaat terhadap peningkatan prestasi belajar, media powerpoint berbasis presentasi dengan slide-slide Powerpoint dengan gambar-gambar dan video yang relevan dengan materi pelajaran akan mengubah perilaku peserta didik dalam mengikuti jalannya pembelajaran yang berbeda pula (Elpira \& Ghufron, 2015). Media ini juga cocok untuk kelas gemuk (Jalil, 2016).

Cukup mengejutkan peneliti dalam angket ketiga terkuak bahwa pelatihan yang diberikan kepada mahasiwa PGMI semester 4 ini termasuk sesuatu hal baru bagi mereka. Dari angket yang dianalisis terdapat $87,5 \%$ mahasiswa menyatakan pelatihan pengembangan materi melalui slide presentasi ini termasuk sesuatu yang baru. Respon mahasiswa terkait kebaruan disajikan pada Gambar 4 berikut.

\section{RESPON MAHASISWA}

BARU CUKUP BARU

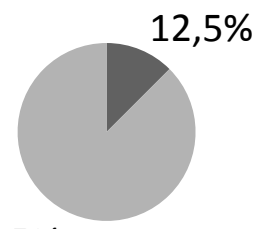

$87,5 \%$

Gambar 4 Respon Mahasiswa Terkait Pernyataan Kebaruan Terhadap Pelatihan

\section{Kesulitan dan Kendala Mahasiswa dalam Pelatihan}

Hasil angket didapat 50\% mahasiswa menyatakan kesulitan dalam menyusun struktur dan konten materi. Hal dikarenakan karena dalam pelatihan tidak disiapkan terlebih dahulu referensi yang dibutuhkan untuk mengembangkan sub materi. Dalam mengembangkan materi melalui slide presentasi hendaknya sudah mencari berbagai literatur yang akan dimasukkan ke ruang kerja Powerpoint, sehingga konten yang dimasukkan tidak ala kadarnya.
Sebesar 25\% mahasiswa kesulitan membuat template sendiri. Template pada Powerpoint sebenarnya sudah disediakan oleh MS Powerpoint dan menjadi bawaan program Office. Namun template yang ada masih sangat sederhana dan cenderung kurang menarik. Untuk itu pelatihan ini dilatihkan membuat template sehingga tampilan slide Presentasi lebih menarik dan elegan. Hasil penelitian menunjukkan banyak tayangan slide dalam bidang pendidikan lebih buruk dari tayangan slide bisnis. Hal ini diperlihatkan dari desain presentasi yang tidak jelas dan tidak selalu intuitif (Kosslyn, Kievit, Russell, \& Shephard, 2012). Bentuk template selama proses latihan dapat dilihat pada Gambar 5 berikut.

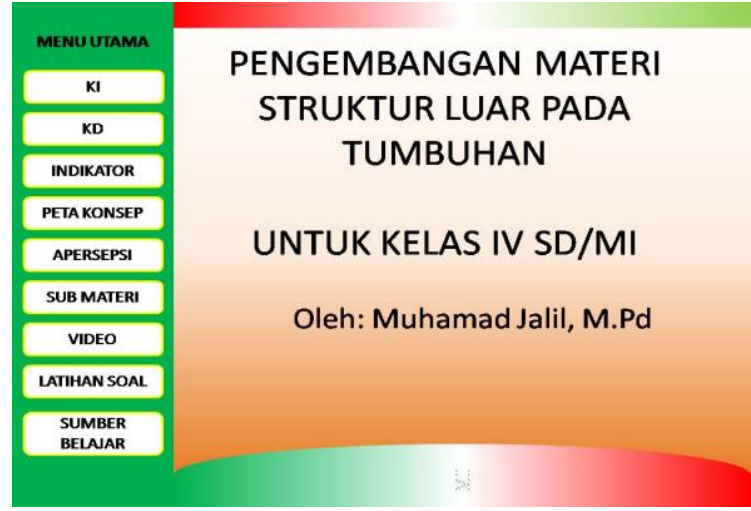

Gambar 5 Tampilan Template Pelatihan Pengembangan Materi

Sebesar $12,5 \%$ siswa kesulitan membuat Hyperlink. Hyperlink digunakan untuk menghubungkan slide satu dengan slide yang lain. Dan 12,5\% menyatakan kesulitan memasukkan windows media player ke dalam slide presentasi. Kendalanya adalah sebagian laptop mahasiswa belum diinstall WMP di laptop. Grafik kesulitan mahasiswa dalam pelatihan pengembangan materi dapat ditunjukkan pada Gambar 6 berikut. 


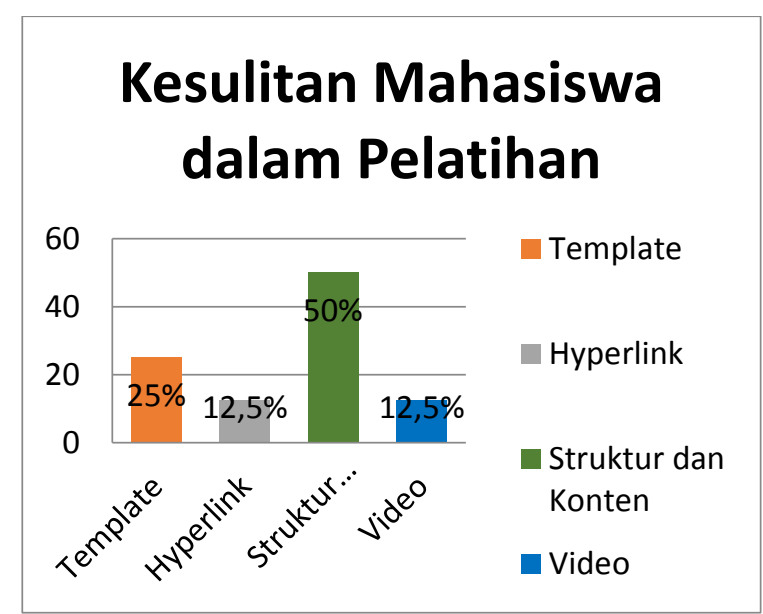

Gambar 6 Kesulitan Mahasiswa Dalam Pelatihan

Kendala yang dihadapi selama proses pelatihan adalah waktu, SDM, dan keberadaan laptop. Waktu menjadi persoalan tersendiri tatkala jadwal pelatihan sudah dijadwalkan namun terbentur dengan agenda di luar pembelajaran. Terbukti dari angket yang dibagikan kepada mahasiwa sebesar 62,5\% menyatakan waktu menjadi catatan mahasiswa sebagai kendala dalam proses pelaksanaan pelatihan pengembangan materi. Pada saat pelatihan kelas PGMI-D kebetulan berbarengan dengan rapat keprodian yang agendanya sama pentingnya. Hal ini membuat pengajar harus mencari hari lain sebagai pengganti jadwal yang seharusnya direncanakan namun tertunda. Disamping itu kelas PGMI LK-A juga mempersoalkan waktu yang terbatas. Apalagi pelatihan yang dilakukan dilangsungkan pada hari Jumat yang biasa disebut sebagai hari yang pendek. Kendala lain berupa tersedianya sarana prasarana yang terbatas. Tidak semua mahasiswa memiliki laptop untuk mendukung keberhasilan proses pelatihan. Mahasiswa yang belum memiliki laptop hanya dapat mencatat langkah-langkah dalam mengembangkan materi di buku tulis. Kendala umum selama pelatihan dapat dilihat pada Gambar 7 berikut.

\section{Kendala Umum Selama Pelatihan}

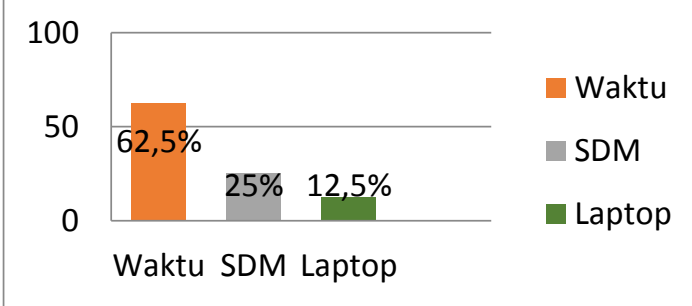

Gambar 7. Kendala Umum Selama Pelatihan Pengembangan Materi

Ada juga mahasiswa menyebut SDM sebagai kendala dalam melakukan pelatihan. Peneliti memiliki pandangan bahwa tidak semua mahasiswa berasal dari sekolah yang fasilitas komputernya lengkah. Hal ini terlihat banyaknya mahasiswa $(87,50 \%)$ yang menyatakan pelatihan pengembangan materi adalah hal baru.

\section{Simpulan}

Pelaksanaan pelatihan pengembangan materi dalam bentuk slide Powerpoint pada materi struktur luar tumbuhan pada kelas IV MI dengan melalui tiga tahapan yaitu pra pelatihan, pelatihan dan evaluasi. Pelatihan meliputi 10 menu yaitu: pembuatan judul, kompetensi inti, kompetensi dasar, indikator, peta konsep,apersepsi, sub materi struktur luar pada tumbuhan, memasukkan windows media player, latihan soal, dan sumber belajar. Seluruh peserta pelatihan menyatakan senang terhadap pelatihan pengembangan materi melalui slide presentasi, $75 \%$ menyatakan bermanfaat, dan 87,25\% menyatakan pelatihan Powerpoint merupakan sesuatu hal yang baru. Kesulitan materi yang dihadapi mahasiswa adalah $50 \%$ berupa penyusunan struktur dan konten materi, 25\%berupa pembuatan template Powerpoint, masing-masing $12,5 \%$ kesulitan membuat hyperlink dan memasukkan windows video player. Kendala teknis yang dihadapi secara umum adalah $62,5 \%$ berupa pengaturan waktu, $25 \%$ SDM, dan $12, \%$ persediaan laptop yang terbatas. 


\section{Referensi}

Arikunto, S. (2013). Dasar-Dasar Evaluasi Pendidikan (2nd ed.). Jakarta: PT Bumi Aksara.

Elpira, N., \& Ghufron, A. (2015). Pengaruh Penggunaan Media Powerpoint Terhadap Minat Dan Hasil Belajar Ipa Siswa Kelas Iv Sd. Jurnal Inovasi Teknologi Pendidikan, 2(1), 94-104.

Eryanti, I. (2015). Pengaruh Strategi Belajar Peta Konsep Terhadap Ketuntasan Belajar Matematika Siswa. FIBONACCI: Jurnal Pendidikan Matematika dan Matematika, 1(2), $45-58$. https://doi.org/10.24853/fbc.1.2.45-58

Harahap, M. N. (2015). Kompetensi Inti dan Kompetensi Dasar dalam Kurikulum 2013. Retrieved May 7, 2018, from https://www.kompasiana.com

Jalil, M. (2016). Pengembangan Pembelajaran Model Discovery Learning Berbantuan Tips Powerpoint Interaktif Pada Materi Interaksi Makhluk Hidup Dengan Lingkungan. REFLEKSI EDUKATIKA, 6(2). https://doi.org/10.24176/re.v6i2.604

Jalil, M. (2018). Peningkatan Aktivitas Dan Hasil Belajar Siswa Materi Tsunami Melalui Metode Diskusi Inkuiri Disertai Penerapan Media Powerpoint Pada Siswa Kelas X SMK Roudlotus Saidiyyah. Genetika, 1(1). Retrieved from http://journal.stainkudus.ac.id/index.php/G enetika/article/view/3265.

Jayanto, A. D. (2011). Slide Presentasi ala Steve Jobs. Jakarta: PT Gramedia.

Kahoot. (2018). Kahoot! | Learning Games | Make Learning Awesome! Retrieved June 3, 2018, from https://kahoot.com/welcomeback/

Kosslyn, S. M., Kievit, R. A., Russell, A. G., \& Shephard, J. M. (2012). PowerPoint ${ }^{\circledR}$ Presentation Flaws and Failures: A Psychological Analysis. Frontiers in
Psychology, 3. https://doi.org/10.3389/fpsyg.2012.00230

Milles, \& Huberman. (1992). An Expanded Sourcebook Qualitative Data Analysis. London: SAGE Publication.

Priatmoko, S., Prasetya, A. T., \& Hartati, S. (2011). Komparasi Hasil Belajar Siswa Dengan Media Macromedia Flash Dan Microsoft Powerpoint Yang Disampaikan Melalui Pendekatan Chemo-Edutaintment. Jurnal Inovasi Pendidikan Kimia, 2(2). Retrieved from https://doaj.or.

Sugiyono. (2010). Metode Penelitian Pendidikan Pendekatan Kuantitatif, Kualitatif dan $R \& D$. Bandung: Alfabeta.

Syahrowardi, S., \& Permana, A. H. (2016). Desain Handout Multimedia Menggunakan 3D Pageflip Professional untuk Media Pembelajaran pada Sistem Android. JPPPF (Jurnal Penelitian Dan Pengembangan Pendidikan Fisika), 2(1), 89-96. https://doi.org/10.21009/1.02113 